\title{
Jaranan Krido Budoyo as the Preservation of Javanese Traditional Arts in Riau Malay Land
}

\author{
Wahyuning Tiyas ${ }^{1}$ Trie Hartiti Retnowati ${ }^{2}$
}

\author{
${ }^{1}$ School of Arts Education, Yogyakarta State University, Yogyakarta, Indonesia \\ ${ }^{2}$ School of Arts Education, Yogyakarta State University, Yogyakarta, Indonesia \\ *Corresponding author. Email: wahyuningtiyas.2018@student.uny.ac.id
}

\begin{abstract}
Riau has been commonly recognized as a Malay region, but some of its areas are occupied by migrants, especially from Java, such as Sialang Sakti village. These village dwellers strive to preserve Javanese art and culture even though they live in the Malay region of Riau. The effort was channeled by establishing a Javanese arts community named Jaranan Krido Budoyo. Jaranan - a dance with traditional hobbyhorses - is a customary art that is popular in Java, especially in rural villages. Not only does it preserve Javanese art and culture, but it also seeks to prove that local arts can develop even far from its originating area. The sounds of Javanese gamelan, dance, and singing unquestionably attract many not only Javanese populations but also other ethnic groups. The reaction of the surrounding community seems very positive, unveiled by the large number of spectators who watched this artistic performance. Jaranan Krido Budoyo has gone through various districts in Riau and has performed at various celebrations. The educational value reserved is to respect cultural differences, love of one's own indigenous culture, and appreciate the existing local arts.
\end{abstract}

Keywords: Jaranan, preservation, Javanese art, Malay

\section{INTRODUCTION}

Java is one of the most populous islands in Indonesia. To overcome the population congestion in one area, the government held a population distribution program known as transmigration. This transmigration program has existed since the colonialization era in 1905. Quoted from the book 'Transmigrasi Masa Doeloe, Kini dan Harapan Kedepan' (Transmigration of the Past Period, Today, and Future Hopes) [2], transmigration was first brought to attention by Ir. Soekarno in 1927. The first transmigrant moved in to one of the provinces in Lampung and from then on, the rest of the transmigrants scattered all over Indonesia. the first placement was marked by 155 families from Kedu, Central Java moving to Gedongan Tataan, Lampung Province. The term transmigration itself was stated by the first President of Indonesia, namely Ir. Soekarno in 1927. Transmigration was needed not only for equal distribution of the population, but also for area development throughout Indonesia.

Riau is one of the destinations for transmigration areas. The transmigrants from Java moved to an area called the Trans area by local people. One of the transmigration areas, becoming a village, is Sialang Sakti. It is part of Dayun District, Siak Regency, Riau Province. In Sialang Sakti Village, transmigration started in the era of President Suharto's governance. Until now, Sialang Sakti Village is one area quite developed with the level of education ranging from kindergarten to high school. The villagers consist of several tribes such as Batak, Malay, Minang, and Javanese as the most dominant.
Although living in Malay land, to maintain the original culture that they brought, Javanese continues to use their language to communicate with other residents. However, the Javanese language used is not the polite one, but the rough Javanese language that has been contaminated with the local language to produce its own accent. In addition, another effort was to establish a Javanese art community, namely Jaranan Krido Budoyo community in 2008 by one of the community leaders. This art is based on Jaranan Banyumasan in Central Java. With this art, Javanese people in Sialang Sakti can still enjoy the popular Javanese performances. This community is arguably the only one that exists and is well known to spread to several regencies in Riau.

There are three things discussed in this paper, namely: "What is Javanese art found in Riau?", "What is the form of Javanese art?", and "How is preservation of Javanese art in Riau?" With these questions, the aim of this study is "to find out the Javanese arts in Riau", "the forms of Javanese arts in Riau", "and the preservation of the existing Javanese arts". The significance of this paper is that the writer participates in developing the art community in the Sialang Sakti Village; through this article many people will know that even though a lot of Javanese live outside Java; they will never forget their culture. Even though it is in a remote area, the art still survives and continues to grow until now. With the existence of Javanese art, it means that local residents know well the original arts and culture. Schools teach a variety of knowledge on Malay arts even though the majority of teachers are Javanese. Malay dance competition is held every year by high schools in Sialang Sakti Village and students at schools wear traditional Malay clothes every 
Friday. This can be an appreciation to the various cultures that exist, as stated by Purwadi [7]. Purwadi [7] stated that in the context of national and state life, social life rests on cultural values as a basis for national identity that cannot be eliminated. In this way it can be the basis that differences are complementary in life. In this way, it can be the basis that differences of life are complementary.

\section{LITERATURE REVIEW}

\subsection{Traditional Art}

Kesenian (art) comes from the word seni which in Malay means 'small'. During the Malay kingdom, this meaning was used by the lower classes who used to work as sculptors and other arts workers [9]. Art itself is identical with beauty that influences people to be attracted to it. Art is an attitude and behavior that has a beautiful nature where the trait affects the human soul in looking at an art itself [8] Art is identical with beauty that impresses people. All human attitudes and behaviors that have a beautiful character and can affect other human souls are called art [8]. It can satisfy the artists as the creators; the process is done by pouring all the creativity and developing it in the form of art performances that can grow happiness and experience that cannot be obtained in other fields.

'Traditional' can be interpreted as something passed down by ancestors and preserved until now. From the word 'traditional', most people think that it is something old like a regional dance. It is considered traditional if the routines follow the customs or norms inherited from the ancestors. The cultural heritage passed down from the ancestors includes traditional weapons, games, and medicines. The word 'traditional' is also familiar in the field of music and dance, meaning that these two fields have existed since long time ago and been preserved until now.

Popular traditional art in this article is what is mostly found among the people, one of which is jaranan. It is taken from the word 'Jaran' which means 'horse' in English, so that the property and its movements depict horsemen.

\subsection{Traditional Art Preservation}

Art is close to culture where culture is a habit that continues to be done by humans until now. Culture in this art form can be interpreted as an expression that has an aesthetic value so that it can be enjoyed by people. Art consists of several types including music, fine art, theater, and dance. The form of preservation discussed in this paper is dance art. The introduction of Indonesian cultural values is not enough just to read or through lessons in schools. Dance art can be used as a medium to introduce cultural values, an effort to get to know cultural values that are not enough to only read or learn in schools [5]. Watching a traditional performance is a form of appreciation in which the artist will feel highly valued in providing entertainment, and it is considered as a means of public education about traditional art that is presented. Art and culture are heritage and an identity of an area. That is why it is important to preserve the arts and culture that we have, so that they will not easily disappear. Traditional art is the cultural and social identity of the local community, and it is a legacy that holds the values of local wisdom that have lived for centuries [10]. Then, the traditional art that exists in the community functions as a medium for delivering messages indirectly. They convey both knowledge on traditional art itself and moral or social issues that occur in society.

Preservation is an effort to maintain something that has existed for a long time. Preservation of traditional art is an effort to maintain traditional art itself as a means of providing knowledge about the art to many people through performances or other media. Indonesia is known as a diverse nation with cultures in each region. For this reason, each region has its own characteristics also used as the identity of the region. Preserving the existing traditional art will also provide knowledge to the next generation about the art forms such as dances, accompaniment music, and costumes. The preservation of Indonesian traditional art is very important to be done so that the existing identity is not gone by time. As argued by Irhandayaningsih [12], the current of globalization provides a change in people's lifestyles where art also undergoes changes from era to era. This is an important note on how art can adapt to the development from time to time.

\subsection{Jaranan}

Jaranan is a popular traditional art in Java, especially in rural communities. Jaranan or jathilan or jaran kepang art is not only for entertainment but also for calling both human and animal spirits. The summoned spirits vary according to what is desired such as the spirits of female dancers, giants, monkeys, tigers, and so on. Jathilan or also called totemism is a tradition of summoning animal spirits [6]. This part of the summon highly attracts the audience's attention. The existence of this jaranan art is purely as folk entertainment and as a preservation of local art; it is different from Jathilan in Java which is also intended to drive evil spirits away. The era development as it is today does not make the existence of jaranan away. Instead, it makes this traditional art more attractive with fresh ideas by art activists. Like Jaranan Krido Budoyo, in every presentation there is always something new that can make the audience hypnotized to keep watching this show. 


\section{METHOD}

The approach to obtain data on the problems that were scientifically studied was the phenomenological method included in qualitative research. Phenomenology is a philosophical movement pioneered by Edmund Husserl (1859-1938) and is one of the most influential thoughts in the 20th century [1]. As the name implies, phenomenology talks about appearances or observing a phenomenon (change) that is around [4]. A phenomenon comes naturally without any setting including social phenomena about their views and experiences related to traditional arts. The steps taken are to avoid all assumptions that refer to art, cultural, and religious experiences, and let them of knowledge explain. There are two types of phenomenology that exist, namely hermeunitic phenomenology that talks about life experiences to interpret texts and transcendental phenomenology that describes the experiences of research participants [3] This transcendental phenomenology was used as a reference in collecting data summarized by conducting triangulation, namely observation, interviews, and documentation. Cresswell [3] also explains that phenomenology must be with individuals who experience phenomena (visible changes) and can reduce personal experience in its processing.

The data collection was carried out in Sialang Sakti Village, Dayun District, Siak Regency, Riau Province. In Sialang Sakti, there is a Javanese traditional art community named Jaranan Krido Budoyo which adopted the Banyumasan jaranan. Interviews were conducted with the members of the community and the local residents with various tribes. Documentation was done by taking photos and videos during the event. Data triangulation was needed to analyze data by interpreting them into broader meanings and visualizing them in writing.

\section{FINDINGS AND DISCUSSION}

Riau is one of the provinces in Sumatra Island where the original tribe is Malay. However, in the period of transmigration held by President Suharto there were many Javanese residents who came and spread throughout Riau Province. Siak Regency, precisely in the village of Sialang Sakti, is one of the villages with quite many transmigrants, so that a lot of cultures are indirectly created. To be able to preserve their original culture, one community was created, namely Jaranan Kridho Budoyo which was also supported by the surrounding community. This is the only Javanese community in Siak Riau Regency and the culture preserver of Javanese art.

Jaranan or Jaran Kepang or Kuda Kepang is the show performed by of this community. Jaranan Krido Budoyo is similar to Jaranan Banyumasan because bothgamelan and dance performances take the basic motion and gamelan
Banyumasan. The pioneer of the establishment of Jaranan Krido Budoyo is a well-known community figure in Sialang Sakti, namely Mr Rochman from Banyumas. He is one of the people who are settled in the economic and social aspects. Jaranan Krido Budoyo was established on May 5, 2008 and to date there are 27 permanent members consisting of 20 men, 5 women, and 2 children. It is indeed dominated by men because the spirit possession scene in each stage has a fairly long duration. Women will perform the opening dance; when the spirit possession scene starts, female dancers will leave, but sometimes they also participate in the scene.

This jaranan art performance takes 2-3 hours and is carried out twice a day, day and night. The show is divided into four parts, namely opening, main show I, main show II, and closing. The accompaniment music is gamelan which consists of some instruments such as kendang, saron, gender, bonang, kethuk kenong, kempul, and gong (Javanese music instruments). The type of music played is ladrang gambuh, lancaran, eling-eling banyumasan, srepek manyuro, waru doyong, kumudo rangsang, and jengkar umbul-umbul (Javanese songs). The accompanied music will change according to the needs of the show. Besides accompaniment music, there is one sinden (singer) who sings during the performance. The main role in Jaranan Krido Budoyo's art performances lies on the dancers because they form the visualization of the show, apply makeup, and wear costume to attract the audience's attention. They used fantasy makeup with their own creations, while the costume includes a head tie, community t-shirt, trousers, socks, jingle, jarik (cloth), stagen (corset), kamus timang (accessories), keris (weapon), and sampur (dancing scarf). The property used during the show is a whip and a braid horse.

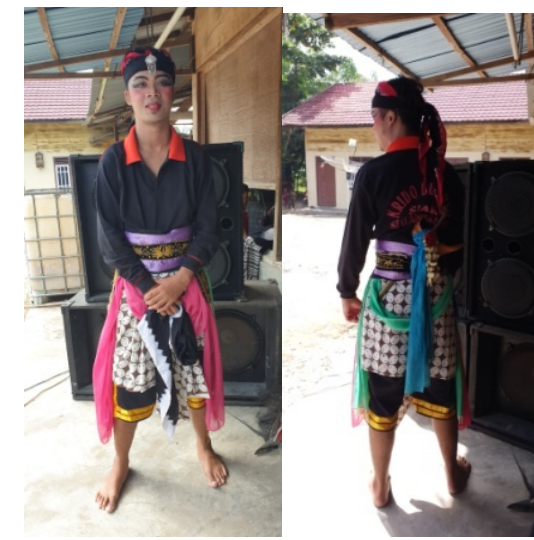

Figure 1 The costume from the front and back sides (photo: Tiyas, June 2019) 


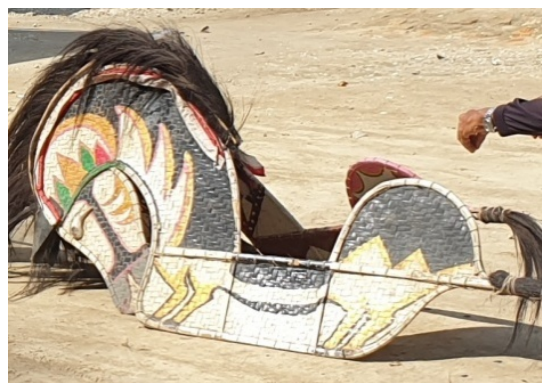

Figure 2 Braid Horse Property (photo: Tiyas, June 2019)

A performance will be easier to understand if there is a plot or parts made. Each part of the scene has its own story that is visualized by the dance moves and songs. The scene is brokendown into as follows:

\subsection{Opening}

The beginning of the show opens with the accompaniment and campursari (Javanese music) singing from Sinden. Before starting a show, a shaman will usually recite prayers so that the show runs smoothly. Then, the shaman will circle the arena by burning incense. Dancers start by shaking hands with all members of the organization and a number of spectators, followed by dancers performing lengger, srakrak, and baladewa dances as the opening act.

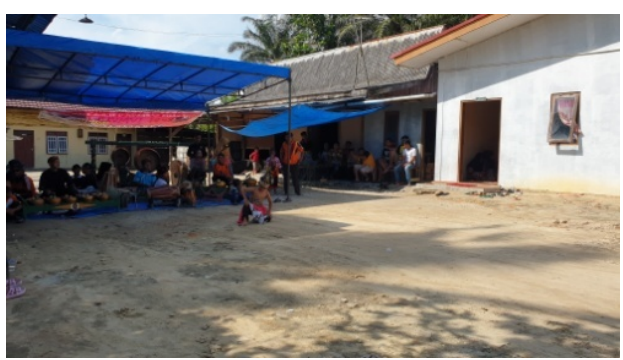

Figure 3 The opening scene with baladewa dance (photo : Tiyas, June 2019)

\subsection{Main Show I}

In this scene, dancers perform a rampak dance using the property. It is a typical dance from the Jaranan Krido Budoyo community.

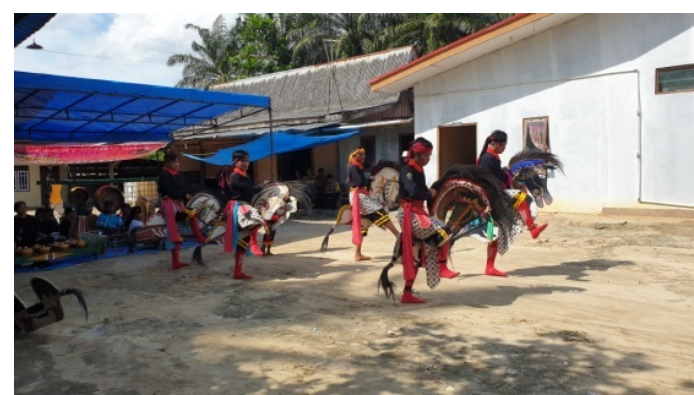

Figure 4 Jaranan Krido Budoyo's traditional rampak kuda dance (photo: Tiyas, June 2019)

\subsection{Main Show II}

This scene comes to the top of the show which is a spirit possession scene. These acts which either intentionally call the spirit or do not are always present. There are various kinds of spirits possessing the dancers such as women, nursing mothers, giants, monkeys, tigers, cats, and those will be different in each show.

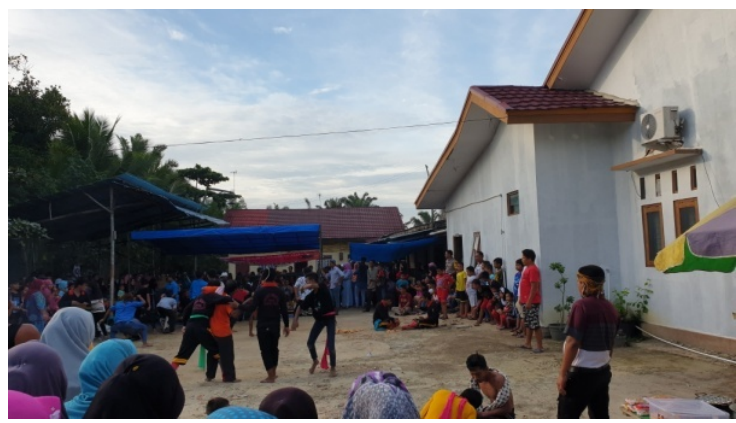

Figure 5 Communication with the audience in the Trance scenes (photo: Tiyas, June 2019)

The final scene of the whole show is done by a shaman who revives the dancers one by one. After all returns to normal, the sinden will sing the ending song as a sign that the show is over.

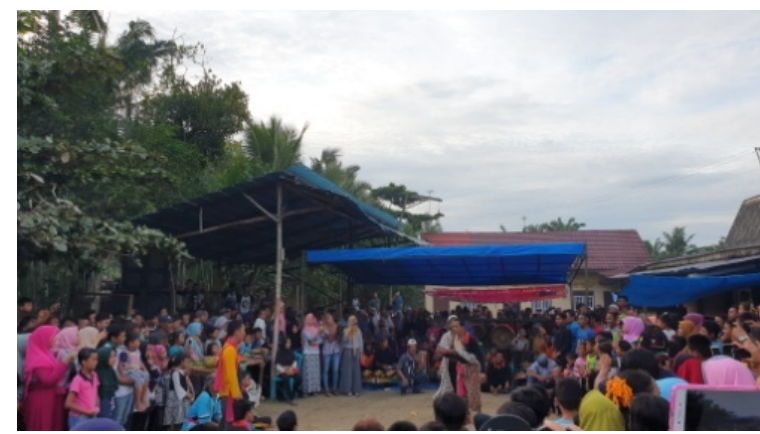

Figure 6 Closing Scene (photo : Tiyas, Juni 2019)

The dance movements used in Jaranan Krido Budoyo are simple, but they can hypnotize the surrounding audience. Moreover, there are child dancers who are able to perform the whole dance. In the rampak dance scene, it is not uncommon for the audience to join the dance and enter the dance arena. The dancers will stop when it comes to the spirit possession scene as the main show. The shaman will get into the arena with offerings prepared, and then call on the spirits to enter, and dancers unconsciously do the performance. Spirit possession acts are quite risky because the audience can participate in the scene. When the spirit 
possession scene is felt to be enough, the shaman will revive the dancers.

Jaranan Krido Budoyo is usually performed at the village's halal bihalal (gathering) event and is used a means of entertainment. Also, not a few are invited to perform at weddings, circumcisions, and other private events. The flow of the show remains the same, but only for accompaniment songs and the dance can be different so that the audience will not get bored. The performance has spread to other villages and even other districts such as from Kerinci Regency to Kampar Regency (interview with Trio, 20 June 2019). The interviewee is one of the community members who have been participating since grade 2 of elementary school up to now in the 12th grade of Vocational High School, and he is majoring in music at Banyumas Karawitan Art High School. Meanwhile, He trains dancers with dances he is self-taught by watching videos and making their own creations. This indicates that advanced information technology in the current era such as the presence of social media has helped the development of Javanese traditional arts, especially those developed in other regions. The social media used in the promotion of the Javanese art community are facebook and Youtube. The use of the social media is appropriate to see the numbers of the viewers/visitors.

Many people assume that traditional Javanese culture is ancient art, close to the magical world, and does not make money. However, Jaranan Krido Budoyo is able to survive in an age and to compete, and its existence is recognized in Malay land, marked by appreciation from the surrounding community where not only the Javanese people watch this Jaranan show. Concern to keep preserving Javanese art is paid off with a community that continuously exists in this II, and closing scenes. At the beginning of the performance, Banyumasan dances such as sigrak, lengger, and baladewa are performed. The dance performed could be different in each show. The certain scenes are the typical community's rampak jaranan dance and spirit possession. The scene is the main attraction for other tribes. The Javanese traditional art community teaches how to love their own arts, culture, and to introduce Javanese arts to other tribes.

\section{REFERENCES}

[1] Adian, Donny Gahral. Pengantar fenomenologi [Introduction to phenomenology]. Penerbit Koekosan, 2010.

[2] A. Ratna Dewi. "Transmigrasi Masa Doeloe, Kini, dan Harapan Kedepan [Past, Present, and Future Transmigration]". Direktorat Jendral Penyiapan Kawasan dan Pembangunan Permukiman Transmigrasi, Direktorat Bina Potensi Kawasan Transmigrasi. 2015 day. It is not an easy thing to maintain this art community in Riau Malay land. However, it is possible to do, for example Javanese art in North Sumatra where Naiborhu [11] Local art is difficult to enter in the era of modernization, in order to survive the potential of the existing sei must be explored to adjust existing changes.For this reason, the potential of traditional art must be explored, so that it can continue to survive. These efforts have been carried out through performances, although they are still held in areas with transmigration residents from Java as well.

\section{CONCLUSION}

Jaranan is one of the popular traditional arts in Java, especially in the villages. This simple and easily recognizable performance art is chosen to be preserved in Riau Province, precisely in the village of Sialang Sakti, Siak Regency. Jaranan Krido Budoyo is the name of a Javanese traditional art community in the village of Sialang Sakti, Dayun District, Siak Regency, Riau Province established on May 5, 2008, which has existed until now. The community has 27 members including 20 men, 5 women, and 2 children The performances are held at various events in the village, one of which is halal bihalal held by the village as the public entertainment. This Javanese traditional art community has extended to various regencies in Riau. The great society appreciation has made this community able to survive in various regions.

Jaranan Krido Budoyo takes the basic dance and accompaniment of Banyumasan. The show is done with four scenes including opening, main show II, main show

[3] Creswell, John W. "Penelitian Kualitatif \& Desain Riset Memilih Diantara

4] Hasbiansyah, O. "Pendekatan Fenomenologi: Pengantar Praktik Penelitian dalam Ilmu Sosial dan Komunikasi [Phenomenology Approach: Introduction to Research Practices in Social Sciences and Communication]." Mediator: Jurnal Komunikasi 9.1 (2008): 163-180.200.

DOI: https://doi.org/10.29313/mediator.v9i1.1146

[5] Hidajat, Robby. "Tari Pendidikan (Pengajaran Tari untuk Pendidikan[Dance Education. Teaching Dance for Education]." Yogyakarta: Penerbit Media Kreativa Yogyakarta (2018).

[6] Kuswarsantyo, Kuswarsantyo. "Seni Jathilan dalam Dimensi Ruang Dan Waktu [The Art of Jathilan in Dimension of Space and Time]." Jurnal Kajian Seni 1.1: 48-59. . DOI: https://doi.org/10.22146/art.5875

[7] Purwadi. "Seni Budaya Jawa di Kabupaten Serdang Bedagai: Ditinjau dari Segi Sosiokultural Filosofi 
[Javanese Arts and Cultures in Serdang Bedagai Regency: Examining from the Sociocultural Aspect of Philosophy]." Published on International Conference 'The Challenges of Cultural Revitalization in the 2015 ASEAN Economic Community Era'. 2014. https://docplayer.info/44260478-Seni-budaya-jawa-dikabupaten-serdang-bedagai-ditinjau-dari-segisosiokultural-filosofis-1.html

[8] Soemantri, S. Ypsi, and L. M. Indrayani. "Upaya Pelestarian Kesenian Khas Desa Mekarsari dan Desa Simpang, Kecamatan Cikajang, Kabupaten Garut [Art [Art Preservation Efforts in Mekarsari Village and Simpang Village, Cikajang District, Garut Regency] ." Dharmakarya 4.1 (2015).

[9] S. Jakob. "Filsafat Seni [Philosophy of Art]." Penerbit ITB: Bandung. 2000

[10] T. Muhammad, Pelestarian Seni Budaya Tradisi dan Nilai Kepemimpinannya Oleh Masyarakat [Preservation of Traditional Arts, Culture, and the Value of Leadership by the Community]. Departemen Etnomusikologi USU: Medan. 2011

[11] Naiborhu, Torang, and Nina Karina. "Ketoprak, Seni Pertunjukan Tradisional Jawa di Sumatera Utara: Pengembangan dan Keberlanjutannya [Ketoprak, Traditional Javanese Performing Arts in North Sumatra: Development and Sustainability]." Panggung 28.4 (2018).DOI: http://dx.doi.org/10.26742/panggung.v28i4 .714

[12] Irhandayaningsih, Ana. "Pelestarian Kesenian Tradisional sebagai Upaya dalam Menumbuhkan Kecintaan Budaya Lokal di Masyarakat Jurang Blimbing Tembalang [Traditional Arts' Preservation as an Effort in Fostering Love of Local Cultures in Tembalang Blimbing Community]." Anuva: Jurnal Kajian Budaya, Perpustakaan, dan Informasi 2.1 (2018): 19-27. DOI: 10.14710/anuva.2.1.19-27 